\title{
Effect of copper and phosphate on the biosynthesis of palladium nanoparticles by Shewanella oneidensis MR1
}

Zheng, Zhiyong; Xiao, Yong; Cao, Huili; Tian, Xiaochun; Wu, Ranran; Zhang, Jingdong; Ulstrup, Jens; Zhao, Feng

Published in:

ChemElectroChem

Link to article, DOI:

10.1002/celc.202001151

Publication date:

2020

Document Version

Peer reviewed version

Link back to DTU Orbit

Citation (APA):

Zheng, Z., Xiao, Y., Cao, H., Tian, X., Wu, R., Zhang, J., Ulstrup, J., \& Zhao, F. (2020). Effect of copper and phosphate on the biosynthesis of palladium nanoparticles by Shewanella oneidensis MR1. ChemElectroChem, 7(21), 4460-4468. https://doi.org/10.1002/celc.202001151

\section{General rights}

Copyright and moral rights for the publications made accessible in the public portal are retained by the authors and/or other copyright owners and it is a condition of accessing publications that users recognise and abide by the legal requirements associated with these rights.

- Users may download and print one copy of any publication from the public portal for the purpose of private study or research.

- You may not further distribute the material or use it for any profit-making activity or commercial gain

- You may freely distribute the URL identifying the publication in the public portal 


\section{ChemElectroChem}

\section{Fhemistry Europe}

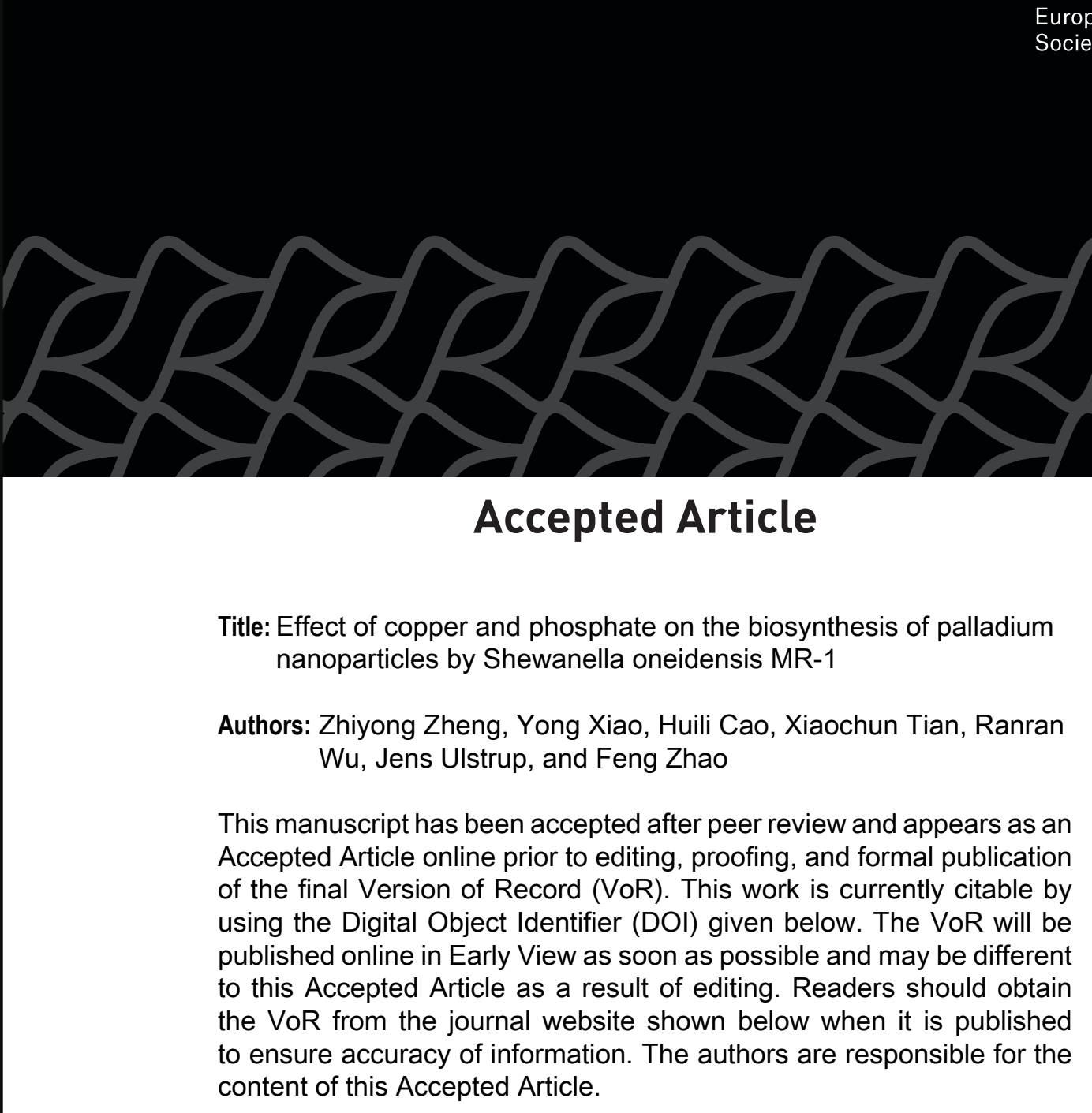

To be cited as: ChemElectroChem 10.1002/celc.202001151

Link to VoR: https://doi.org/10.1002/celc.202001151 


\title{
Effect of copper and phosphate on the biosynthesis of palladium nanoparticles by Shewanella oneidensis MR-1
}

Zhiyong Zheng, ${ }^{[\mathrm{a}]}$ Yong Xiao, ${ }^{[\mathrm{b}]}$ Huili Cao, ${ }^{[\mathrm{a}]}$ Xiaochun Tian, ${ }^{[\mathrm{b}]}$ Ranran $\mathrm{Wu},{ }^{[\mathrm{c}]}$ Jingdong Zhang, ${ }^{\dagger}{ }^{[a]}$ Jens Ulstrup, ${ }^{[a]}$ Feng Zhao*[b]

[a] Dr. Z. Zheng, H. Cao, Prof. Jingdong Zhang, Prof. J. Ulstrup

Department of Chemistry, Technical University of Denmark

Kemitorvet, Building 207, Kongens Lyngby, DK-2800, Denmark

[b] Dr. Y. Xiao, Dr. X. Tian, Prof. F. Zhao

CAS Key Laboratory of Urban Pollutant Conversion, Institute of Urban Environment, Chinese Academy of Sciences

1799 Jimei Road, Xiamen, 361021, China

E-mail:fzhao@iue.ac.cn

[c] Dr. R. Wu

Tianjin Institute of Industrial Biotechnology, Chinese Academy of Sciences

32 West 7th Avenue, Tianjin Airport Economic Area, Tianjin, 300308, China

$[\dagger]$ Deceased

\begin{abstract}
The biosynthesis of metallic nanomaterials, especially noble metal nanomaterials, has attracted extensive attention due to the multifarious potential applications of these materials. In this study we have explored the effects of $\mathrm{Cu}(\mathrm{II})$ on $\mathrm{Pd}(\mathrm{II})$ removal, and of $\mathrm{Cu}(\mathrm{II})$ as well as phosphate on the morphologies and composition of biogenic nanoparticles (NPs) from aqueous Pd(II) systems by Shewanella oneidensis MR-1 (MR-1). Cu(II) causes a slight efficiency decrease of Pd(II) removal by MR-1, but a high removal efficiency of $89.8 \%$ is still achieved, which contrasts sharply with the significant inhibition to other microbes. Without phosphate buffer in the medium, 5-nm PdNPs densely envelop MR-1 and accumulate significantly in the periplasm in the absence of $\mathrm{Cu}(\mathrm{II})$, while 4-nm PdNPs are evenly distributed in the periplasm, and the cellular surface is smooth in the presence of
\end{abstract}


$\mathrm{Cu}(\mathrm{II})$. The following effect of $\mathrm{Cu}(\mathrm{II})$ on PdNP synthesis by MR-1 is therefore proposed: $\mathrm{Cu}(\mathrm{II})$ significantly affects PdNPs morphologies by inhibiting $\operatorname{Pd}(0)$ transfer across the outer membrane and PdNP crystal growth in the periplasm, but not the sorption of Pd(II). Phosphate addition only slightly increases Pd harvest but also precipitates $\mathrm{Cu}(\mathrm{II})$ and poses difficulties for the biosynthesis. The study highlights the effect of co-existing metals during the biosynthesis of metallic nanomaterials and offers new insight into the mechanism of PdNP formation and the electron transfer during $\mathrm{Pd}(\mathrm{II})$ reduction by MR-1.

\section{Introduction}

Extracellular electron transfer (EET) is a ubiquitous and fundamental process in nature, and important to the understanding of the redox chemical processes in microbial cells, including the microbial biosynthesis of nanomaterials. Microorganisms can reduce metal ions to corresponding metallic nanomaterials through detoxification mechanisms. In a sense, they act as "green" nanofactories and harvest nanomaterials cost-effectively. ${ }^{[1]}$ Microbes can synthesize different metallic nanomaterials individually and concurrently. S. putrefaciens CN32 was, for example, reported to recycle Au(III), $\mathrm{Co}(\mathrm{II})$, and $\mathrm{Fe}(\mathrm{II})$ with absorption capacities as high as 1346, 335, and $302 \mathrm{mg}$ metals/g biomass from aqueous systems. ${ }^{[2]}$ Pseudomonas aeruginosa SM1 can synthesize amorphous $\mathrm{Ru}, \mathrm{Rh}, \mathrm{Co}, \mathrm{Ni}$, and Li NPs, and crystalline Ag, Fe, Pd, and PtNPs inside the cell (Co and Li) and on the cell surface (Ag, Pd, $\mathrm{Fe}, \mathrm{Rh}, \mathrm{Ni}, \mathrm{Ru}$, and Pt). ${ }^{[3]} \mathrm{A}$ mixture of PdNPs and AuNPs as precursors of a highly efficient electrocatalyst was produced by MR-1 after the addition of $\left[\mathrm{PdCl}_{4}\right]^{2-}$ and $\left[\mathrm{AuCl}_{4}\right]^{-}$into the medium. ${ }^{[4]}$ The biosynthetic nanomaterials show some exclusive properties compared to their chemosynthetic counterparts. Zhang and associates showed, for example, that PdNPs synthesized on the surface of MR-1 selectively catalyze the electrochemical oxidation of formate but not of ethanol, methanol, and acetate. ${ }^{[5]}$

Many investigations to map the interactions between microorganisms and metals (including the corresponding biogenic metallic nanomaterials) have been reported. ${ }^{[6-10]}$ The biosynthesis of metallic nanomaterials by microbes is, however, highly complex. The complexity originates from the inherent EET processes and external factors such as the medium. The key processes in the biosynthesis of metallic nanomaterials are the biosorption and the redox reactions of metals on the microbial surface 
and within the microorganisms. ${ }^{[11,12]}$ EET, which triggers redox reactions in microbes, is complicated because of the complex microbial structures and the adaptability of the microbes. Mechanistic studies of the microbial EET process are thus highly valuable. ${ }^{[13]}$

One of the microbial structures is extracellular polymeric substances (EPS), through which microbes exchange electrons with the environment. By comparing the microbes (Shewanella oneidensis MR-1, Bacillus sp. WS-XY1, and Pichia stipites) with and without EPS, Zhang and associates showed that EPS facilitates indirect EET by electron "hopping" through the electron transit media. ${ }^{[14]}$ The adaptability allows microbes to adapt to different environments. In another recent study, Zhang and associates discovered that Shewanella oneidensis MR-1 (MR-1) immobilized on electrodes can accept electrons from six different specific redox molecules including $\left[\mathrm{Fe}(\mathrm{CN})_{6}\right]^{4-3-}$ and shows asymmetric voltammetry with enhanced anodic and lowered cathodic peak current. ${ }^{[15]}$ No similar voltammetry of other bacteria under the same experimental conditions is known. ${ }^{[15,16]}$ Further study of $\left[\mathrm{Fe}(\mathrm{CN})_{6}\right]^{4-3-}$ revealed that the electrocatalysis involves two processes: MR-1 first oxidizes $\left[\mathrm{Fe}(\mathrm{CN})_{6}\right]^{4-}$ and transfer electrons into the cell; $\left[\mathrm{Fe}(\mathrm{CN})_{6}\right]^{3-}$ then relays electrons from MR-1 to the electrode. ${ }^{[15]}$ The ability of MR-1 to oxidize redox molecules contrasts established knowledge of this bacterium and possibly correlates closely with the specific environment.

The biogenic nanomaterials can differ for a specific microbe cultured in media with a different composition such as buffers and other metals. The influence of buffer on the chemical synthesis of nanomaterials has been widely studied. Zhang and associates investigated the effect of six buffers (2(N-morpholino)ethanesulfonic acid, piperazine, phosphate, ammonium acetate, 4-(2-hydroxyethyl)-1piperazineethanesulfonic acid, and tris(hydroxymethyl)aminoethane) on the morphologies of the resulting biogenic AuNPs. The AuNP diameters from 2-(N-morpholino)ethanesulfonic acid and phosphate were $4 \pm 1 \mathrm{~nm}$ and $13 \pm 2 \mathrm{~nm}$ respectively, but the AuNPs are not stable without buffer. ${ }^{[17]}$ PtNP diameters were, however, found to be less affected by different buffers with NP diameters from phosphate, 2-(N-morpholino)ethanesulfonic acid, and ammonium acetate buffer being $1.8 \pm 0.5,1.7 \pm$ 0.2 and $1.6 \pm 0.5 \mathrm{~nm}$, respectively. ${ }^{[18]}$ In addition, some buffer agents precipitate certain metal ions in the aqueous system. They are also possibly redox-active and interfere in redox reactions between microbes and metal ions, chelate with metal ions, or produce radicals. ${ }^{[19,20]}$ Buffer agents are typically 
included in the biosynthesis media to maintain the microbial viability. Nonetheless, the buffer effect on the biosynthesis of NPs is often ignored. The presence of metal ions in the medium possibly interferes with the reactions of other metals, including their redox reactions. In some cases, given metal ions can promote the formation of other metallic or semi-metallic NPs. For example, Fe(III) facilitates the reduction of $\mathrm{Te}(\mathrm{IV})$ to $\mathrm{Te}(0)$ by $\mathrm{MR}-1$, resulting in extracellular $\mathrm{Te}(0)$ nanorods, while only a few intracellular $\mathrm{Te}(0)$ nanorods were observed without $\mathrm{Fe}(\mathrm{III}) .{ }^{[21]}$

Noble metal nanomaterials, such as Pd nanomaterials, have received significant attention due to their outstanding performances in various applications. ${ }^{[1]}$ The biosynthesis of nobel metal nanomaterials has been regarded as a promising approach due to its environmental-friendly nature. However, with multiple metal ions in the medium, a given metal ion can be reduced to form solid NPs prior to NP formation of the other metals. The presence of the solid metal NPs thus has a dual effect on the other metals. The NPs can sterically obstruct the mass transfer of metal ions into the periplasm and cytoplasm, and impede the redox reactions of the metal ions on the microbial surface or within the cells. For instance, the electrocatalytic oxidation of $\left[\mathrm{Fe}(\mathrm{CN})_{6}\right]^{4-}$ by MR-1 was found to decrease monotonously with the increasing amount of PdNPs on the outer membrane surface, ${ }^{[15]}$ but the presence of specific NPs enhances the EET. ${ }^{[22,23]}$ The reduction of metal ions on the cellular surface is thus facilitated, and the formation of the metallic NPs promoted. $\mathrm{Cu}(\mathrm{II})$ is one of the various metals that can significantly affect microbial metabolism. Despite that copper is an important component to specific proteins, ${ }^{[24-26]}$ $\mathrm{Cu}(\mathrm{II})$ is also an inhibitor of the hydrogenases in the periplasm. ${ }^{[27,28]}$ Hydrogenases are reported to participate in a wide variety of metal reductions, including the reduction of $\mathrm{Au}(\mathrm{III})$ and $\mathrm{Pd}(\mathrm{II})$ by Escherichia coli, ${ }^{[11,12]}$ and of $\mathrm{Pd}(\mathrm{II})$ by MR-1. ${ }^{[29]} \mathrm{Cu}(\mathrm{II})$ in the medium would thus hinder the reduction of other metals, especially those controlled by hydrogenases in the periplasm. ${ }^{[12,27,28]}$ MR-1 was recently found to reduce $\mathrm{Cu}(\mathrm{II})$ and form $\mathrm{CuNPs}$ both intracellularly or extracellularly, ${ }^{[30]}$ but the resulting influence on the biosynthesis of other metallic nanomaterials remains unanswered. It is therefore highly desirable to explore further the complex intermetallic synergy or antagony in the biosynthesis of multiple metallic nanomaterials, especially bimetallic and trimetallic nanomaterials.

In this study, we investigate specifically the effect of $\mathrm{Cu}(\mathrm{II})$ on the biosynthesis of PdNPs by MR-1. The influence of $\mathrm{Cu}$ (II) on $\mathrm{Pd}(\mathrm{II})$ removal efficiency in aqueous solution was first assessed. Particularly 
the morphologies, elemental compositions, and structure of the hybrids of MR-1 cells with PdNPs in the presence and absence of $\mathrm{Cu}(\mathrm{II})$ and phosphate buffer are detailed. The mechanisms of PdNP formation in the presence and absence of $\mathrm{Cu}$ (II) and phosphate buffer are discussed next. The results disclose the notable role of $\mathrm{Cu}$ (II) on the morphological regulation of PdNPs and offer a comprehensive view of the impact of phosphate buffer on the PdNP biosynthesis. The study thus reveals the interactions between the microbes and metals as well as between the co-existing metals, and demonstrates a potential method to control the morphology of metallic nanomaterials synthesized by microbes.

\section{Experimental}

\section{Chemicals}

Luria-Bertani broth (LB, $10 \mathrm{~g} \mathrm{~L}^{-1}$ tryptone, $5 \mathrm{~g} \mathrm{~L}^{-1}$ yeast extract, $\left.5 \mathrm{~g} \mathrm{~L}-1 \mathrm{NaCl}\right), \mathrm{Na}_{2} \mathrm{HPO}_{4} \cdot 12 \mathrm{H}_{2} \mathrm{O}$ (99 101 \%), $\mathrm{KH}_{2} \mathrm{PO}_{4}(98 \sim 100.5 \%), \mathrm{NH}_{4} \mathrm{Cl}$ ( $\left.\geq 99.5 \%\right), \mathrm{CaCl}_{2} \cdot 2 \mathrm{H}_{2} \mathrm{O}$ (99\%), sodium DL-lactate (60 $\%), \mathrm{HCl}(37 \%)$, and $\mathrm{Na}_{2}\left[\mathrm{PdCl}_{4}\right](98 \%)$, and glutaraldehyde (25\%) were from Sigma-Aldrich, Germany. $\mathrm{NaH}_{2} \mathrm{PO}_{4} \cdot 2 \mathrm{H}_{2} \mathrm{O}(\geq 99.0 \%)$ and $\mathrm{NaCl}(\geq 99.5 \%)$ from Fluka, Germany. $\mathrm{CuCl}_{2} \cdot 2 \mathrm{H}_{2} \mathrm{O}$ (Analytical Reagent) and $\mathrm{MgSO}_{4} \cdot 7 \mathrm{H}_{2} \mathrm{O}(99.8 \%$ ) were from Riedel-de-Haën, France. Absolute ethanol $(100 \%)$ was from VWR Chemicals, France. All chemicals were used as received. Aqueous solutions were prepared with MilliQ water $\left(18.2 \mathrm{M} \Omega \mathrm{cm}\right.$, arium ${ }^{\circledR}$ pro VF system, Sartorius AG, Germany).

\section{Culture and collection of $S$. oneidensis MR-1}

The culture and collection of $S$. oneidensis MR-1 (MR-1) were similar, as reported with some modifications. ${ }^{[15]}$ In brief, MR-1 suspension $(1.0 \mathrm{~mL})$ from $4{ }^{\circ} \mathrm{C}$ fridge was added into $100 \mathrm{~mL} \mathrm{LB}$. The medium was cultured in a temperature-controlled incubator $\left(30^{\circ} \mathrm{C}, 100 \mathrm{rpm}\right)$ for $22 \mathrm{~h}$. The cells were collected by centrifugation, followed by washing twice with $0.9 \% \mathrm{w} / \mathrm{w} \mathrm{NaCl}$ aqueous solution. The pellets obtained were suspended in $15 \mathrm{~mL} 0.9 \% \mathrm{w} / \mathrm{w} \mathrm{NaCl}$ aqueous solution and deoxygenated with argon.

\section{Reduction of Pd(II) and Cu(II) by MR-1}


As the brief scheme shown in Figure S1, a $1.0 \mathrm{~mL}$ cell suspension was added to $24 \mathrm{~mL}$ sterilized and deoxygenated $0.9 \% \mathrm{w} / \mathrm{w} \mathrm{NaCl}$ aqueous solution containing $50 \mathrm{mM}$ sodium DL-lactate and metal ion(s). The medium was then cultured in sealed $50 \mathrm{~mL}$ serum bottles. The medium of MR-1 cultured in $0.08 \mathrm{mM} \mathrm{Na}_{2}\left[\mathrm{PdCl}_{4}\right]$ for $48 \mathrm{~h}$ was denoted as $\mathrm{S} / \mathrm{Pd}$ ("S" for Shewanella). Similarly, the medium of MR-1 cultured in $0.08 \mathrm{mM} \mathrm{CuCl}_{2} \cdot 2 \mathrm{H}_{2} \mathrm{O}$ for $48 \mathrm{~h}$ was indicated as $\mathrm{S} / \mathrm{Cu}$. Medium S/CuPd was obtained at $\mathrm{t}=48 \mathrm{~h}$ when $0.08 \mathrm{mM} \mathrm{CuCl}_{2} \cdot 2 \mathrm{H}_{2} \mathrm{O}$ and $0.08 \mathrm{mM} \mathrm{Na}_{2}\left[\mathrm{PdCl}_{4}\right]$ were added into the medium at $\mathrm{t}=0$ and $\mathrm{t}=24 \mathrm{~h}$ respectively. The medium was then filtered through $0.22 \mu \mathrm{m}$ filters. Experiments were conducted in triplicate. The residual $\mathrm{Cu}$ and $\mathrm{Pd}$ in the medium were measured by ICP-OES (Thermo scientific; iCAP 7000 series) prior to dilution with $3 \% \mathrm{HNO}_{3}$ solution.

\section{Preparation of Cu-, Pd-, and CuPdNPs by MR-1}

As the brief scheme shown in Figure S2. A $1.0 \mathrm{~mL}$ cell suspension was added to $24 \mathrm{~mL}$ sterilized and deoxygenated M9 buffer [pH 7.0; $\mathrm{KH}_{2} \mathrm{PO}_{4}\left(3.00 \mathrm{~g} \mathrm{~L}^{-1}\right), \mathrm{Na}_{2} \mathrm{HPO}_{4} \cdot 12 \mathrm{H}_{2} \mathrm{O}\left(15.14 \mathrm{~g} \mathrm{~L}^{-1}\right), \mathrm{NH}_{4} \mathrm{Cl}(1.00$ $\left.\left.\mathrm{g} \mathrm{L}^{-1}\right), \mathrm{NaCl}\left(0.50 \mathrm{~g} \mathrm{~L}^{-1}\right), \mathrm{CaCl}_{2} \cdot 2 \mathrm{H}_{2} \mathrm{O}\left(0.015 \mathrm{~g} \mathrm{~L}^{-1}\right), \mathrm{MgSO}_{4} \cdot 7 \mathrm{H}_{2} \mathrm{O}\left(0.025 \mathrm{~g} \mathrm{~L}^{-1}\right)\right]^{[4]}$ containing $50 \mathrm{mM}$ sodium DL-lactate and metal ion(s). The medium was then cultured in sealed $50 \mathrm{~mL}$ serum bottles. $\mathrm{Na}_{2}\left[\mathrm{PdCl}_{4}\right]$ was added into the serum bottles to a concentration of $0.20 \mathrm{mM}$ at $\mathrm{t}=0$ and the culture maintained until $\mathrm{t}=48 \mathrm{~h}$. The hybrid of MR-1 cells and PdNPs was collected, washed with M9 medium, resuspended in $15 \mathrm{~mL}$ MilliQ water, and then subjected to a microwave process $\left(200^{\circ} \mathrm{C}, 2 \mathrm{~h}\right)$ to terminate the synthesis. The product was denoted as S/Pd-M9_C. $0.10 \mathrm{mM} \mathrm{CuCl}_{2} \cdot 2 \mathrm{H}_{2} \mathrm{O}$ and 0.20 $\mathrm{mM} \mathrm{Na}_{2}\left[\mathrm{PdCl}_{4}\right]$ were added to the medium at $\mathrm{t}=0$ and $\mathrm{t}=24$ respectively to obtain S/CuPd-M9_C. To investigate the effect of phosphate buffer on the biosynthesis, $0.9 \% \mathrm{w} / \mathrm{w} \mathrm{NaCl}$ aqueous solution was replaced by $\mathrm{M} 9$ buffer, and S/Pd-NaCl_C and S/CuPd-NaCl_C obtained accordingly. It should be noted that the sample notations (e.g., CuPd) in the study are for distinction and do not necessarily match the chemical states.

\section{Characterization of biosynthesized NPs}

The preparation of scanning electron microscopy (SEM) samples follows a reported procedure. ${ }^{[15]}$ Briefly, cells were washed with $0.9 \%$ w/w $\mathrm{NaCl}$ aqueous solution, resuspended in $2.5 \%$ glutaraldehyde (prepared with PBS) at $4{ }^{\circ} \mathrm{C}$ for $48 \mathrm{~h}$, washed twice with $50 \mathrm{mM}$ PBS (pH 7.0), and 
dehydrated in a gradient ethanol series $(50,70,80,95 \%)$ for $15 \mathrm{~min}$ each. The cells were finally dehydrated in absolute ethanol (three changes in $15 \mathrm{~min}$ ). The prepared cells were cast on a silicon wafer and allowed to dry overnight at room temperature. Cells coated with $1 \mathrm{~nm}$ gold were observed under SEM (Quanta FEG 200 ESEM, FEI, USA) equipped with energy-dispersive X-ray spectroscopy (EDS) analysis. The prepared cells were placed on copper grids and dried for transmission electron microscopy (TEM, Tecnai G2 T20 instrument (FEI Company, Hillsboro, USA) in imaging mode and selected area electron diffraction mode (SAED).

\section{Results and Discussion}

\subsection{Concurrent reduction of $\mathrm{Cu}$ and Pd by MR-1}

$\mathrm{Cu}(\mathrm{II})$ in the medium was removed to an extent of $48.8 \%$ after cultured for $24 \mathrm{~h}$ and to $72.8 \%$ after $48 \mathrm{~h}$ culture by MR-1 when lactate was the electron donor and $\mathrm{Cu}$ (II) sole electron acceptor (Figure 1A). The slower removal rate during the second $24 \mathrm{~h}$ phase may be caused by the decrease of available $\mathrm{Cu}(\mathrm{II})$ binding and reduction sites of MR-1 cells. With the addition of $\mathrm{Pd}(\mathrm{II})$ to the medium at $\mathrm{t}=24$ $\mathrm{h}, \mathrm{Cu}(\mathrm{II})$ removal efficiency was lower $(60.1 \%)$ at $\mathrm{t}=48 \mathrm{~h}$. The difference in $\mathrm{Cu}(\mathrm{II})$ removal efficiency implies a competition in electron acceptance and active sites between $\mathrm{Cu}(\mathrm{II})$ and $\mathrm{Pd}(\mathrm{II})$, or steric blocking to $\mathrm{Cu}(\mathrm{II})$ transfer by PdNPs.
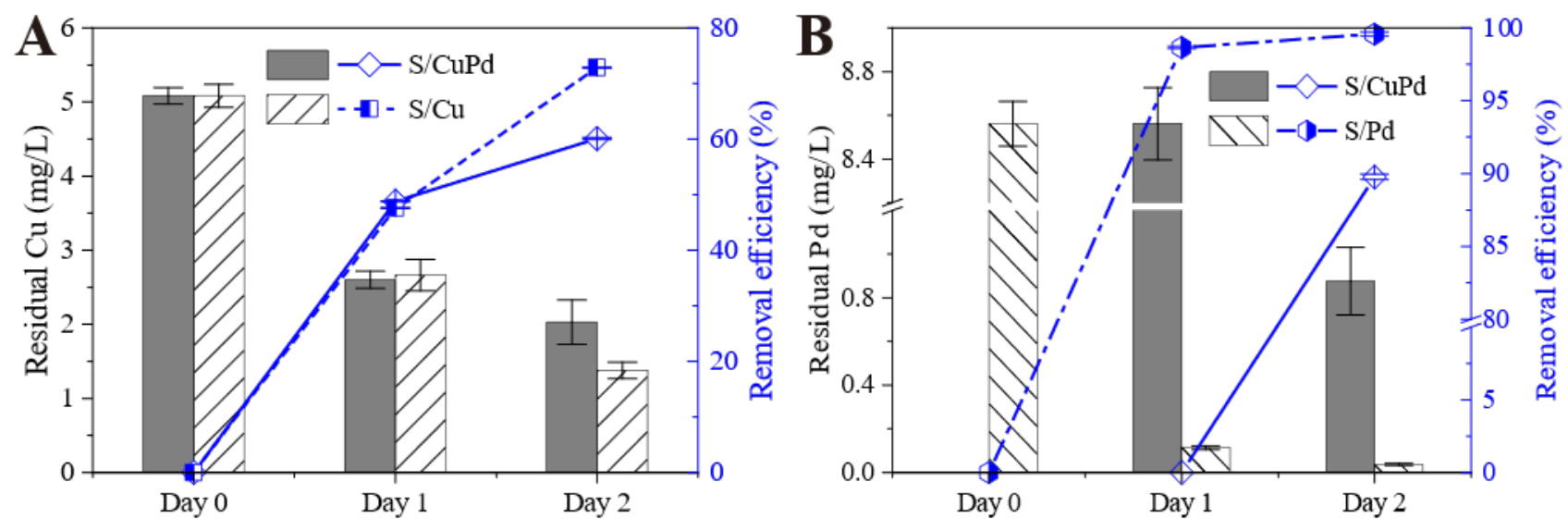

Figure 1. Co-removal of (A) $\mathrm{Cu}$ and (B) $\mathrm{Pd}$ by MR-1. Residual metals in the medium and corresponding removal efficiency are shown. The error bars indicate the standard deviation from triplicate $(n=3)$ experiments. 
Pd(II) removal by MR-1 is fast, and removal efficiency of $98.7 \%$ was accomplished in the first $24 \mathrm{~h}$ (Figure 1B). Another $24 \mathrm{~h}$ culture achieved almost complete removal (99.6\%). Pd(II) reduction is reported to be a fast process, and black solids were observed 10 min after incubating MR-1 in Pd(II) containing medium). ${ }^{[27]}$ The $\mathrm{Pd}(\mathrm{II})$ removal rate slowed down after $1 \mathrm{~h}$ gradually to be equilibrated at $2 \mathrm{~h}$ under aerobic conditions. ${ }^{[31]}$ After $\mathrm{Pd}(\mathrm{II})$ was added to the medium containing $\mathrm{Cu}(\mathrm{II})$ for $24 \mathrm{~h}$, Pd(II) removal was slightly hampered, but high removal of $89.8 \%$ was still achieved (Figure 1B).

The relatively minor impact of $\mathrm{Cu}(\mathrm{II})$ on $\mathrm{Pd}(\mathrm{II})$ removal is unexpected. Similarly to the antibacterial properties of $\mathrm{Ag}(\mathrm{I}),{ }^{[32-34]} \mathrm{Cu}(\mathrm{II})$ can damage the cellular membrane, denature proteins, and result in cell death. ${ }^{[32,33]} \mathrm{Cu}(\mathrm{II})$ is also an inhibitor of periplasmic hydrogenases, which are extensively reported to have one of the key roles in metal ion reduction. ${ }^{[12]}$ As little as $0.05 \mathrm{mM} \mathrm{Cu}(\mathrm{II})$ thus efficiently inhibits the ATPase activity of Enterococcus hirae. ${ }^{[35]}$ Exposed to a medium containing $\mathrm{Cu}(\mathrm{II})$ for half an hour, $\mathrm{Au}(\mathrm{III})$ reduction by E. coli and Desulfovibrio desulfuricans decreased by $50 \%$ and $70 \%$ respectively. ${ }^{[12]}$ Likewise, exposed to $\mathrm{Cu}(\mathrm{II})$ for $10 \mathrm{~min}$, no $\operatorname{Pd}(0)$ NPs were synthesized by Desulfovibrio desulfuricans incubated in a medium with $\mathrm{Pd}(\mathrm{II}) .{ }^{[27]}$ However, MR-1 can survive in environments containing a certain concentration of $\mathrm{Cu}(\mathrm{II})$ and $\mathrm{Ag}(\mathrm{I})$, and produce corresponding NPs. ${ }^{[30,34,36]}$ The growth of MR-1 cultured in $30 \mathrm{mM}$ 3-(N-morpholino)propanesulfonic acid buffer containing $0.01 \mathrm{mM} \mathrm{Cu}(\mathrm{II})$ was $100 \%$ compared to the buffer without $\mathrm{Cu}(\mathrm{II})$, while the growth decreased to $20 \%$ when $\mathrm{Cu}$ (II) increased to $0.10 \mathrm{mM} \cdot{ }^{[30]}$ The resistance of MR-1 to $\mathrm{Cu}(\mathrm{II})$ and $\mathrm{Ag}(\mathrm{I})$ may derive from the EET, which can be a defense mechanism. The minor decrease in Pd(II) removal from $\mathrm{S} / \mathrm{CuPd}$ during the first $24 \mathrm{~h}$ after the $\mathrm{Pd}(\mathrm{II})$ addition (Day 1 to Day 2) compared with S/Pd (Day 0 to Day 1) implies that the capacity to reduce Pd(II) (Figure 1B) is retained.

The Pd(II) reduction by MR-1 was ascribed to the [NiFe]-hydrogenase HyaB in the periplasm instead of the widely studied MtrC/OmcA or CymA in the outer membrane. ${ }^{[29]}$ It is notable that about $50 \%$ of the $\mathrm{Pd}(\mathrm{II})$ reduction is retained in the absence of HyaB. ${ }^{[29]}$ Only parts of $\mathrm{Pd}(\mathrm{II})$ is therefore reduced by $\mathrm{HyaB}$, and other possible pathways different from the MtrCAB-OmcA pathway play a significant role. A NADH dehydrogenase-2 (NDH-2), a quinone oxidoreductase, or an alternative NADH dehydrogenase in the cytoplasm of MR-1, are believed to be responsible for the $\mathrm{Cu}(\mathrm{II})$ reduction by MR-1. ${ }^{[30]}$ The deletion of MtrC, MtrF (a homolog of MtrC), OmcA, MtrABCDEF, DmsE (a 
periplasmic decaheme cytochrome $c$ ), CctA (a periplasmic tetraheme cytochrome $c$ ), and gene SO_4360 (coding for periplasmic decaheme cytochrome $c$ MtrA family ${ }^{[1]}$ ) all have only minor effects on the $\mathrm{Cu}(\mathrm{II})$ reduction by $\mathrm{MR}-1 .{ }^{[30]}$

\subsection{Effect of $\mathrm{Cu}(\mathrm{II})$ on the biosynthesis of PdNPs and characterization of the PdNPs}

To investigate the influence of $\mathrm{Cu}(\mathrm{II})$ on the biosynthesis of PdNPs, MR-1 was cultured in M9 medium containing $\mathrm{Pd}(\mathrm{II})$ and $\mathrm{Cu}(\mathrm{II})$. M9 medium without $\mathrm{Cu}(\mathrm{II})$ was used as a control. Since phosphate in M9 medium possibly precipitates $\mathrm{Cu}(\mathrm{II})$, a low $\mathrm{Cu}$ (II) concentration $(0.10 \mathrm{mM})$ was applied. After the synthesis, MR-1 cells with biogenic PdNPs were killed by a microwave heating processes to stop the synthesis and stabilize the NPs, and to carbonize the biomass and improve the conductivity of the biomass for specific applications in electrochemistry. Hydrothermal processes and high-temperature carbonization are widely used to improve the performance of nanomaterials. ${ }^{[4,37-39]}$ Hydrothermal processes are reported to be a better solution than high-temperature carbonization for preventing the aggregation of the nanomaterials and biomass. ${ }^{[4,37]}$ Microwave heating and hydrothermal heating are similar in applying high temperature and high pressure, but microwave heating outperforms hydrothermal heating by providing homogeneous heating ${ }^{[40]}$ and delicate control.

The structure of S/CuPd-M9_C is shown in Figure 2A and B. The cellular length is smaller than $1 \mu \mathrm{m}$,

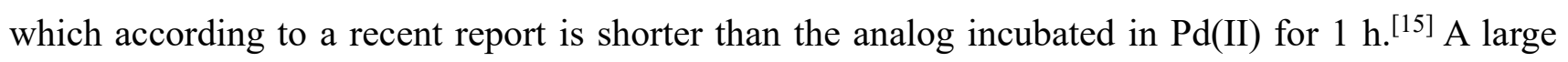
number of PdNPs is spread extracellularly (Figure 2A and B), which contrasts with cell-bound PdNPs in the absence of $\mathrm{Cu}(\mathrm{II}) .{ }^{[15]}$ The cellular surface is smooth compared with the counterpart incubated in medium without $\mathrm{Cu}(\mathrm{II}) .{ }^{[15]} \mathrm{Pd}$ and $\mathrm{Cu}$ signals were both detected in the sample with a comparable amount of cells and extracellular NPs (Site \#1) confirmed by EDS mapping, and the former is much stronger than the latter (Figure S3). The elemental content associated with cells and NPs, i.e., C, N, O, $\mathrm{P}, \mathrm{S}, \mathrm{Pd}$, and $\mathrm{Cu}$, was determined. The element $\mathrm{P}$ from the M9 medium can also be detected if phosphate precipitates form. The molar ratio of the initial concentrations of $\mathrm{Cu}$ (II) $(0.10 \mathrm{mM})$ and $\mathrm{Pd}$ (II) $(0.20$ $\mathrm{mM})$ is $1: 2$. This value is close to the ratio of $\mathrm{Cu}: \mathrm{Pd}(0.81: 2.04)$ of Site \#1 (Figure S3 and Figure S4). However, further EDS of the cells and extracellular NPs offer other details regarding the NP compositions. EDS of a sample with four cells and a pile of extracellular NPs (Site \#2) shows that the dominating elements of the extracellular NPs are C, N, O, P, Cu, and Pd (Figure 2B, C, D, Figure S5, 
and Figure S6). Signals of O, P, and $\mathrm{Cu}$ from the extracellular NPs are stronger than those in the cells (Figure 2C, Figure S5D and E). These NPs are unlikely to be pure $\mathrm{Cu}(0) \mathrm{NPs}$ or $\mathrm{Pd}(0) \mathrm{NPs}$, but complexes comprising CuNPs and PdNPs associated with EPS. A higher molar ratio of Cu: Pd (0.76: 1.05, Figure S6) from the Site \#2 compared with that of Site \#1 (0.81: 2.04, Figure S4) implies that Cu is inclined to accumulate in the extracellular NPs while PdNPs associate with the cells.

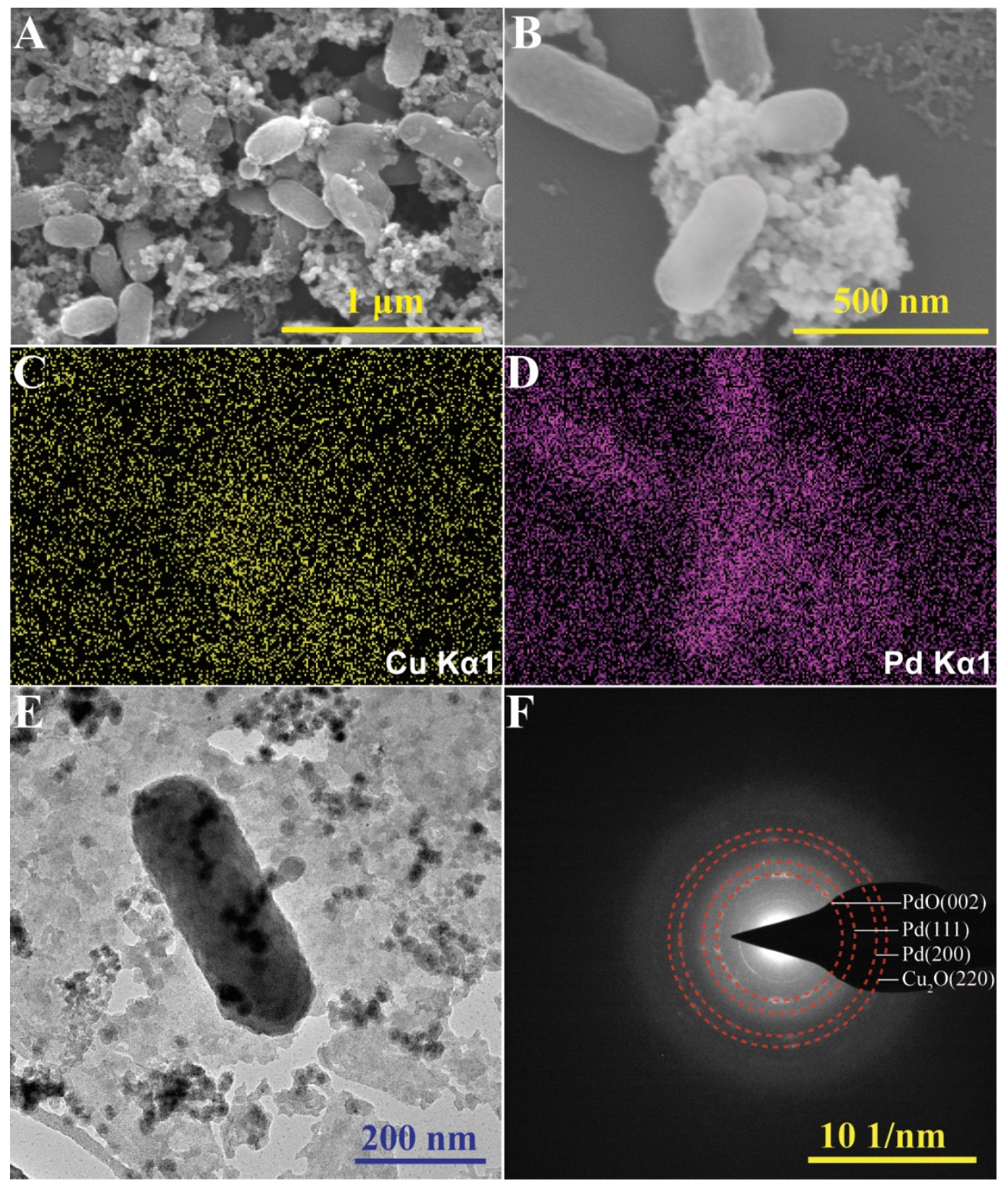

Figure 2. Morphology and composition of S/CuPd-M9_C. (A) SEM image of cells and extracellular NPs. (B) SEM image of Site \#2 with four cells and extracellular NPs. (C) Cu EDS mapping and (D) Pd EDS mapping of Site \#2. The other elemental mappings are shown in Figure S5 and Figure S6. (E) TEM image of a cell enveloped in EPS with small encapsulated NPs. (F) SAED pattern of extracellular NPs. 
Large flower-like structures up to $10 \mu \mathrm{m}$ are observed among the S/CuPd-M9_C hybrids (Figure S7). According to the EDS results, the main elemental composition is $\mathrm{C}, \mathrm{N}, \mathrm{O}, \mathrm{P}$, and $\mathrm{Cu}$ (Figure $\mathrm{S} 7$ and Figure S8). The weak Pd signal is possibly from MR-1 cells attached to the flower-like structure (Figure $\mathrm{S7H}$ ). The molar ratio of $\mathrm{Cu}$ : $\mathrm{Pd}$ of the flower-like structure is as high as 3.91: 0.63, and the content of $\mathrm{O}$ and $\mathrm{P}$ is considerably higher than that of Site \#1 (Figure S3) and Site \#2 (Figure S5). The flower-like structures are therefore most likely precipitates of phosphate and $\mathrm{Cu}(\mathrm{II}) . \mathrm{C}$ and $\mathrm{N}$ signals are probably caused by the sorption of EPS of MR-1 cells. Large extracellular copper agglomerates (above $200 \mathrm{~nm}$ ) were also observed when MR-1 was cultured in 3-(N-morpholino)propanesulfonic acid containing $\mathrm{Cu}(\mathrm{II}) .{ }^{[30]}$ The composition of those agglomerates was not addressed in Ref. [30], but it could be copper precipitates at neutral pH, e.g., $\mathrm{Cu}(\mathrm{II})$ (hydro)oxides.

The NPs were further characterized by TEM and SAED. The NPs are not uniform, with size ranging from $3 \mathrm{~nm}$ to $15 \mathrm{~nm}$. We also observed small NPs spreading on the supporting film of the TEM grid, encapsulated in a polymer structure (possibly EPS), and enveloping the cells (Figure 2E). Clear lattices are observed at high magnifications, implying a crystalline structure (Figure S9). Four dominating patterns were present in SAED of the NPs (Figure 2F). The interplanar distance (d) of the NPs were calculated according to the equation: ${ }^{[41]}$

$$
d=\frac{2}{D}
$$

where $d$ is the interplanar distance $(\mathrm{nm})$ and $D$ the diameter of the ring (or the distance between two symmetric spots) $(1 / \mathrm{nm})$. For a given elemental composition, a specific interplanar distance can be assigned to a corresponding crystal plane. ${ }^{[42,43]}$ The lattice distances of $0.27,0.22,0.19,0.15 \mathrm{~nm}$ obtained are assigned to $\mathrm{PdO}(002), \mathrm{Pd}(111), \mathrm{Pd}(200)$, and $\mathrm{Cu}_{2} \mathrm{O}(220)$ respectively. ${ }^{[30,44-46]} \mathrm{A}$ similar pattern of $\mathrm{Cu}_{2} \mathrm{O}(220)$ in Figure $2 \mathrm{~F}$ was reported in the $\mathrm{Cu}_{2} \mathrm{O}$ NPs obtained by MR-1 cultured with $\mathrm{Cu}(\mathrm{II})$ as the sole electron acceptor. ${ }^{[30]}$ The presence of $\mathrm{PdO}$ indicates that a considerable amount of Pd(II) was not completely reduced by MR-1, and that the respiration of which was potentially inhibited by $\mathrm{Cu}(\mathrm{II})$. The presence of $\mathrm{Cu}_{2} \mathrm{O}$ structures suggests that the reduction of $\mathrm{Cu}(\mathrm{II})$ is incomplete, or that $\mathrm{Cu}(0) \mathrm{NPs}$ are oxidized when exposed to the air. 
The structure of S/Pd-M9_C is shown in Figure 3. The cellular length of S/Pd-M9_C is larger than S/CuPd-M9_C, indicating growth inhibition of MR-1 caused by $\mathrm{Cu}(\mathrm{II})$. The great majority of the cells are entirely encapsulated with PdNPs, forming a thick and rough coating. This coating contrasts with the sparse coating on MR-1 cells incubated in as high as $0.80 \mathrm{mM}$ of $\mathrm{Pd}(\mathrm{II})$ for $1 \mathrm{~h} \cdot{ }^{[15]} \mathrm{As}$ noted, $\mathrm{Pd}(\mathrm{II})$ recovery by MR-1 is therefore a rapid process, but one hour is not enough to allow the complete formation of PdNPs on the cellular surface under the current experimental conditions. Some cells are free of PdNPs coating, as indicated by the red arrow in Figure 3B. These cells have probably multiplied after the available Pd(II) was consumed. The bacterial re-birth confirms that bacterial viability in the M9 medium with $\mathrm{Pd}(\mathrm{II})$ is retained. Most NPs are attached to the cellular surface, which is different from the NPs spread out in S/CuPd-M9_C (Figure 2A and B). EDS mapping reveals the elemental compositions of the MR-1 cells, including Pd, C, N, O, P, and S (Figure 3D, Figure S10, and Figure S11). The NPs clothing of the cells are PdNPs. The atomic ratio of Pd is as high as $5.55 \%$ (a mass ratio of $31.37 \%$ ). This value is at least twice higher than that of S/CuPd-M9_C (Figure S4, Figure S6, and Figure S8). 

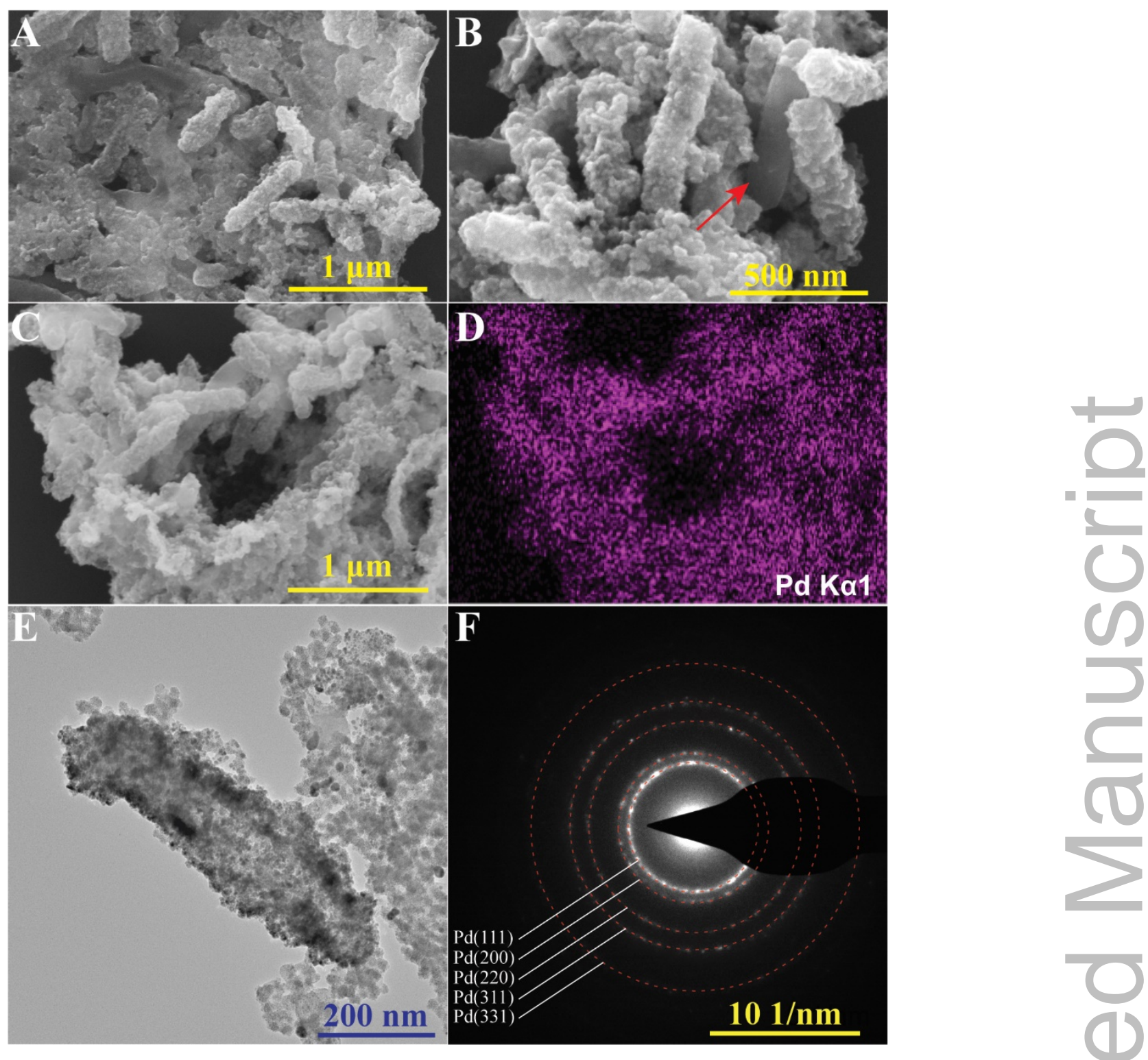

Figure 3. Morphology and composition of S/Pd-M9_C. (A) and (B) SEM images at different magnifications. The red arrow in (B) indicates a cell without PdNP coverage. (C) SEM image and (D) the corresponding Pd EDS mapping. The other elemental mappings are shown in Figure S10 and Figure S11. (E) TEM image of a cell completely covered by PdNPs. (F) SAED pattern of the PdNP coating.

The PdNPs on S/Pd-M9_C were further characterized by TEM and SAED (Figure 3E and F). Polymer structures, possibly EPS, link the PdNPs (Figure 3E). The coverage of NPs with a size of 5 $10 \mathrm{~nm}$ on the cell surface is quite dense (Figure S12). It is difficult to confirm that PdNPs have formed in the periplasm as reported, ${ }^{[29,31]}$ but PdNPs apparently attach to the outer membrane. No separate PdNP is observed on the supporting film. Crystal lattices are observed (Figure S12B), but not as clear as 
S/CuPd-M9_C (Figure S9). Pd(111) and Pd(200) are observed in SAED as S/CuPd-M9_C. Additional lattice distances of $0.14,0.12$, and $0.09 \mathrm{~nm}$ are assigned to $\operatorname{Pd}(220), \operatorname{Pd}(311)$, and $\operatorname{Pd}(331)$ respectively (Figure $3 \mathrm{~F})$. $\operatorname{Pd}(\mathrm{II})$ was hence completely reduced to $\operatorname{Pd}(0)$, and crystalline $\operatorname{Pd}(0)$ NPs were formed. In summary, the cellular surface is densely covered with PdNPs in the absence of $\mathrm{Cu}(\mathrm{II})$, but is smooth in the presence of $\mathrm{Cu}(\mathrm{II})$. With the interference of $\mathrm{Cu}(\mathrm{II})$, PdNPs probably accumulate in the periplasm. Phosphate seems to precipitate $\mathrm{Cu}(\mathrm{II})$. Media without phosphate buffer is therefore needed for further studies, as detailed in the next section.

\subsection{Effect of phosphate buffer on the biosynthesis of PdNPs by MR-1}

As noted, phosphate precipitates $\mathrm{Cu}(\mathrm{II})$. Aqueous $\mathrm{NaCl}$ solution $(0.9 \% \mathrm{w} / \mathrm{w})$ with $\mathrm{Cu}(\mathrm{II})$ was therefore used to study the effect of phosphate buffer on the biosynthesis of PdNPs. This product is denoted as S/CuPd-NaCl_C. $\mathrm{NaCl}$ solution $(0.9 \% \mathrm{w} / \mathrm{w})$ without $\mathrm{Cu}(\mathrm{II})$ was used as a control, and the product denoted as $\mathrm{S} / \mathrm{Pd}-\mathrm{NaCl}_{-}$C. Compared to pure water, $0.9 \% \mathrm{w} / \mathrm{w} \mathrm{NaCl}$ solution can exclude the influence of phosphate and also provide osmotic pressure crucial to bacterial viability.

The morphologies of S/CuPd-NaCl_C and S/CuPd-M9_C are different, although both are produced by MR-1 cultured in media with $\mathrm{Cu}(\mathrm{II})$ and Pd(II) (Figure 2 and Figure 4). The cellular surface of S/CuPd$\mathrm{NaCl} \_\mathrm{C}$ is as smooth as S/CuPd-M9_C, except the presence of several large particles attached to the surface. All NPs of S/CuPd-NaCl_C are associated with the cells (Figure 4A and B), contrasting the separated NPs from cells observed in S/CuPd-M9_C (Figure 2A and B). The large NPs resemble the ones observed on the MR-1 cells incubated in $0.08 \mathrm{mM} \mathrm{Pd}(\mathrm{II})$ for $1 \mathrm{~h} .{ }^{[15]}$ Note that the medium for $\mathrm{S} / \mathrm{CuPd}-\mathrm{NaCl} \_\mathrm{C}$ contains $0.20 \mathrm{mM} \mathrm{Pd}(\mathrm{II})$ and the culture time is $24 \mathrm{~h} . \mathrm{Cu}(\mathrm{II})$ in the medium therefore interferes with the MR-1 metabolism. The large NPs probably form on active sites excluded from the $\mathrm{Cu}(\mathrm{II})$ inhibition or before the inhibition took effect. Abundant PdNPs are distributed on the cellular surface or inside the cells despite the smooth outer membrane, as supported by the considerable and homogeneous Pd signal in the EDS mapping (Figure 4D). However, according to the EDS data (Figure 4C), the $\mathrm{Cu}$-levels inside the cells are too low to detect. The molar ratio of $\mathrm{Cu}$ : $\mathrm{Pd}$ is 0.08: 2.24 (Figure S13 and Figure S14) and much lower than that of S/CuPd-NaCl_C (Figure S4, Figure S6, and Figure $\mathrm{S} 8$ ). The low ratio is probably due to the absence of copper precipitation in $0.9 \% \mathrm{w} / \mathrm{w} \mathrm{NaCl}$ solution, in contrast to the copper-rich flower structures in the M9 medium. On the other hand, according to the 
EDS data, Pd recovery from $0.9 \% \mathrm{w} / \mathrm{w} \mathrm{NaCl}$ solution is comparable to that from $\mathrm{M} 9$ medium (Figure $\mathrm{S} 14$ and Figure S4). Based on the high removal efficiency of $\mathrm{Pd}(\mathrm{II})$ and $\mathrm{Cu}(\mathrm{II})$ (Figure 1), copper must therefore be accumulated inside the cells and is beyond EDS detection.

S/CuPd-NaCl_C was further investigated using TEM and SAED. Large NPs (40 to $70 \mathrm{~nm}$ ) appear on the cellular surface (Figure 4E). Smaller, about $4 \mathrm{~nm}$, NPs are homogeneously distributed on the cell surfaces (Figure S15A). Lattices of the small NPs are not clear in TEM (Figure S15B), suggesting that the small NPs are perhaps dispersed in the periplasm. The bright SAED spots are from the large crystalline NPs and assigned to $\operatorname{Pd}(111), \operatorname{Pd}(220)$, and $\operatorname{Pd}(311)$. The halo ring is from the small NPs and attributed to $\mathrm{Pd}(111)$ (Figure 4F). Copper crystal patterns are not observed, pointing to low content or amorphous structure of the copper products. The large and small NPs must therefore all be PdNPs.

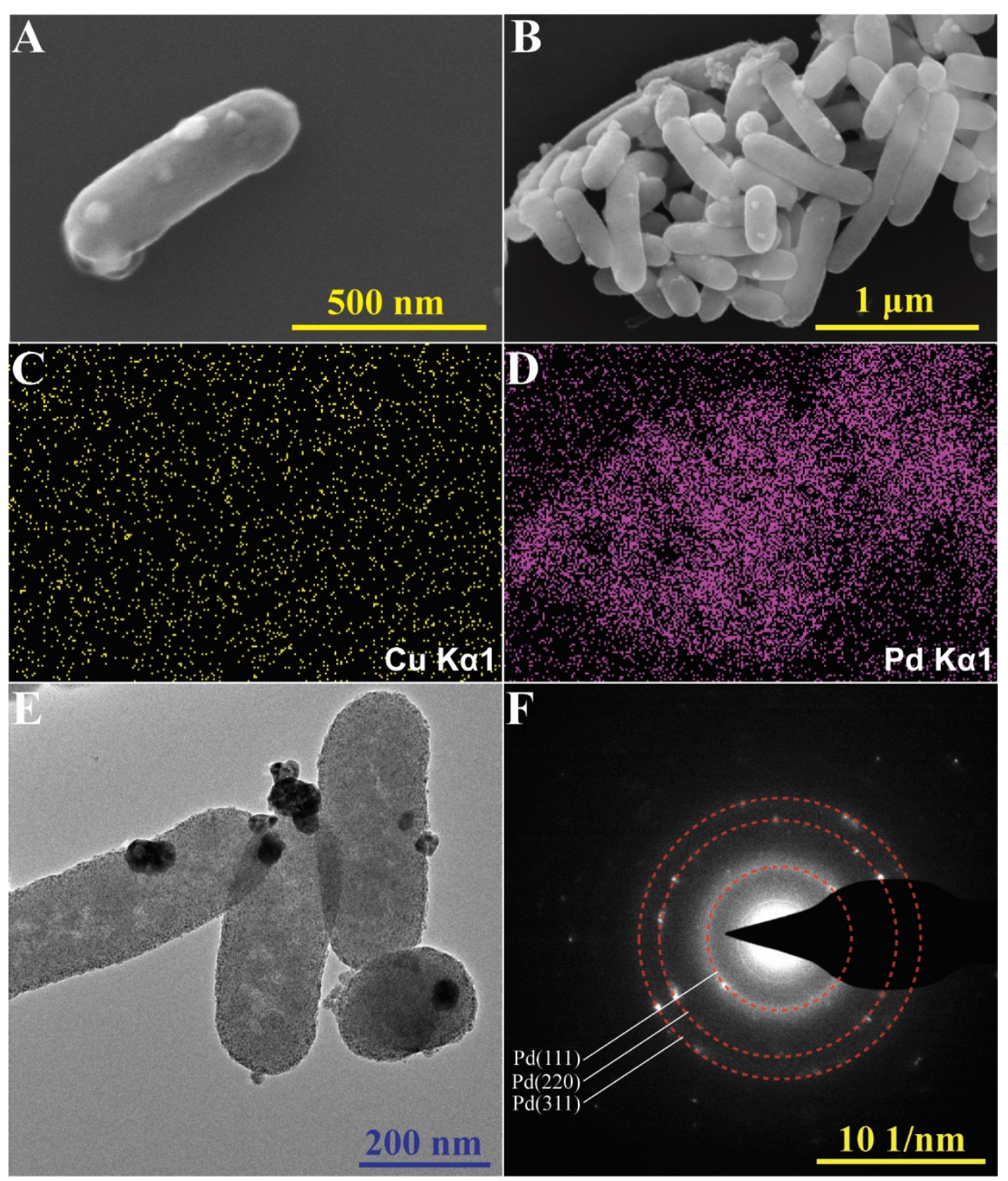


Figure 4. Morphology and composition of S/CuPd-NaCl_C. (A) and (B) SEM images at different magnifications. The white spots are NPs. (C) Cu and (D) Pd EDS mapping of the sample shown in (B). The other elemental mappings are shown in Figure S13 and Figure S14. (E) TEM image showing the homogenous distribution of NPs and several large NPs. (F) SAED pattern of NPs in cells.

The cellular surface of $\mathrm{S} / \mathrm{Pd}-\mathrm{NaCl} \_\mathrm{C}$ cultured in media without $\mathrm{Cu}(\mathrm{II})$ is coarse, but not as rough as S/Pd-M9_C. Less dense and small NPs cover the outer membrane compared to S/Pd-M9_C (Figure 5A and B). The different morphologies of S/Pd-NaCl_C and S/Pd-M9_C are attributed to the effect of phosphate buffer. Notably, elongated MR-1 cells more than $4 \mu \mathrm{m}$ in length were observed (indicated by arrows in Figure 5A). MR-1 cell elongation is reported when cells are cultured in media containing chromium(VI) or cisplatin $\left[\mathrm{Pt}\left(\mathrm{NH}_{3}\right)_{2} \mathrm{Cl}_{2}\right]_{0} \cdot{ }^{[47,48]} \mathrm{Cell}$ division is regulated by the synthesis and turnover of the peptidoglycan (murein) sacculus. ${ }^{[47]} \mathrm{Pd}(\mathrm{II})$ must therefore interfere with the expression of the genes relevant to cell division. A Pd signal on the cells of $\mathrm{S} / \mathrm{Pd}-\mathrm{NaCl} \mathrm{C}$ in the EDS mapping was observed as expected (Figure 5C and D). The NPs on the cellular surface are thus confirmed as PdNPs. The $\mathrm{Pd}$ content of $\mathrm{S} / \mathrm{Pd}-\mathrm{NaCl} \_\mathrm{C}$ is $4.17 \%$ in the atomic ratio or $25.55 \%$ in the mass ratio (Figure S17). This value is slightly lower than that of S/Pd-M9_C, which is $5.55 \%$ in atomic ratio or $31.37 \%$ in mass ratio.

TEM shows that some PdNPs aggregate extracellularly and associate with the cells. Apparent accumulation of PdNPs in the periplasm is observed as indicated by the arrow in Figure 5E. Most of the PdNPs are around $5 \mathrm{~nm}$, slightly larger than that of S/CuPd-NaCl_C. The lattices of the PdNPs could not be observed with adequate clarity (Figure S18). The SAED patterns follow those of S/PdM9_C except for the absence of $\operatorname{Pd}(200)$. The halo ring of Pd(111) confirms the small size of the PdNPs (Figure 5F). 

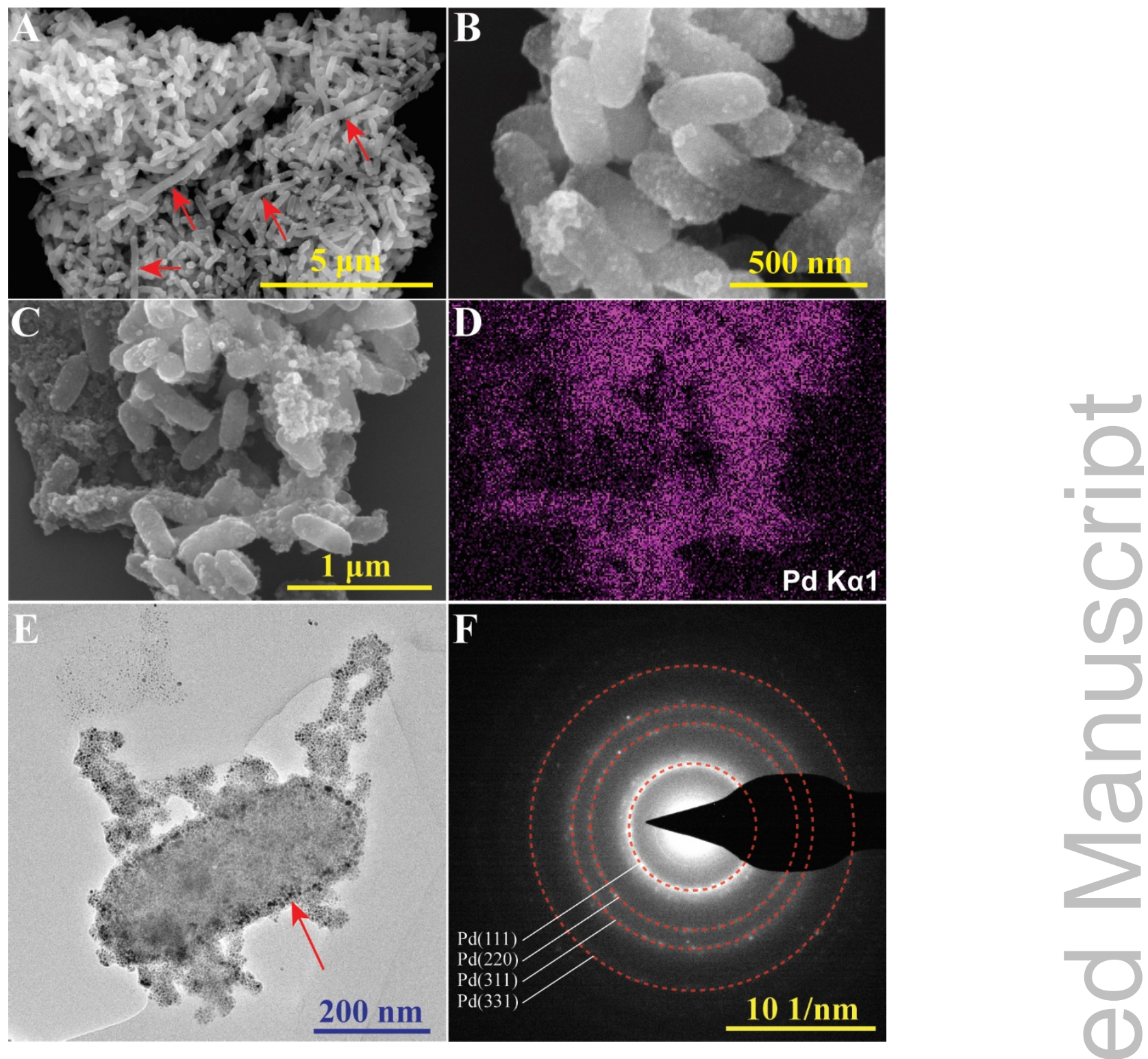

Figure 5. Morphology and composition of S/Pd-NaCl_C. (A) and (B) SEM images at different magnifications. Red arrows in (A) indicate elongated cells. (C) SEM image and (D) corresponding Pd EDS mapping. The other elemental mappings are shown in Figure S16 and Figure S17. (E) TEM image of a cell covered with PdNPs. The red arrow indicates PdNPs accumulation in the periplasm. (F) SAED pattern of NPs associated with cells.

In summary, compared to the counterparts in the M9 medium with phosphate buffer, similarities and differences are discovered in the NPs obtained in the $0.9 \% \mathrm{w} / \mathrm{w} \mathrm{NaCl}$ solution medium containing $\mathrm{Pd}(\mathrm{II})$ and $\mathrm{Cu}(\mathrm{II})$, or Pd(II) alone. Large amounts of small homogenous NPs and several large NPs appear in the cells cultured in $\mathrm{Cu}(\mathrm{II})$ and $\mathrm{Pd}(\mathrm{II})$. Moreover, no $\mathrm{Cu}$ signal was detected. PdNPs accumulated in the periplasm and elongated cells are shown in the cells cultured in $\mathrm{Pd}(\mathrm{II})$. 


\subsection{Proposed mechanism of the effects of $\mathrm{Cu}$ (II) on the morphologies and cellular distribution of biogenic PdNPs}

Part of the $\mathrm{Cu}$ (II) ions precipitates (e.g., copper phosphate and copper hydroxide) in neutral media or media containing phosphate. The precipitates are reduced to $\mathrm{Cu}(\mathrm{I})$ or $\mathrm{Cu}(0)$ by $\mathrm{MR}-1$, leading to the formation of extracellular copper NPs as the flower-like structure in S/CuPd-M9_C (Figure S7). The rest of $\mathrm{Cu}(\mathrm{II})$, or all $\mathrm{Cu}(\mathrm{II})$ (if no precipitates form), interact with MR-1 by biosorption, reduction, and inhibition. MR-1 can absorb $\mathrm{Cu}(\mathrm{II})$ as well as other metal ions and then reduce $\mathrm{Cu}(\mathrm{II})$ intracellularly, such as in the cytoplasm and the periplasm. $\mathrm{Cu}(\mathrm{II})$ primarily inhibits the transfer of the $\operatorname{Pd}(0)$ reduced by MR-1 in the periplasm across the outer membrane. Consequently, most of the Pd(0) NPs accumulate intracellularly instead of extracellularly and result in the smooth cellular surface (Figure 6). Some active sites are excluded from the inhibition and lead to large PdNPs on the cellular surface. The inhibition of $\mathrm{Pd}(\mathrm{II})$ sorption by MR-1 is minor, but the reduction of $\mathrm{Pd}(\mathrm{II})$ to $\mathrm{Pd}(0)$ and the crystal growth of PdNPs are inhibited to a significant extent, leading to PdO formation and smaller PdNP sizes than the PdNPs synthesized in media without $\mathrm{Cu}(\mathrm{II})$ (Figure 6).

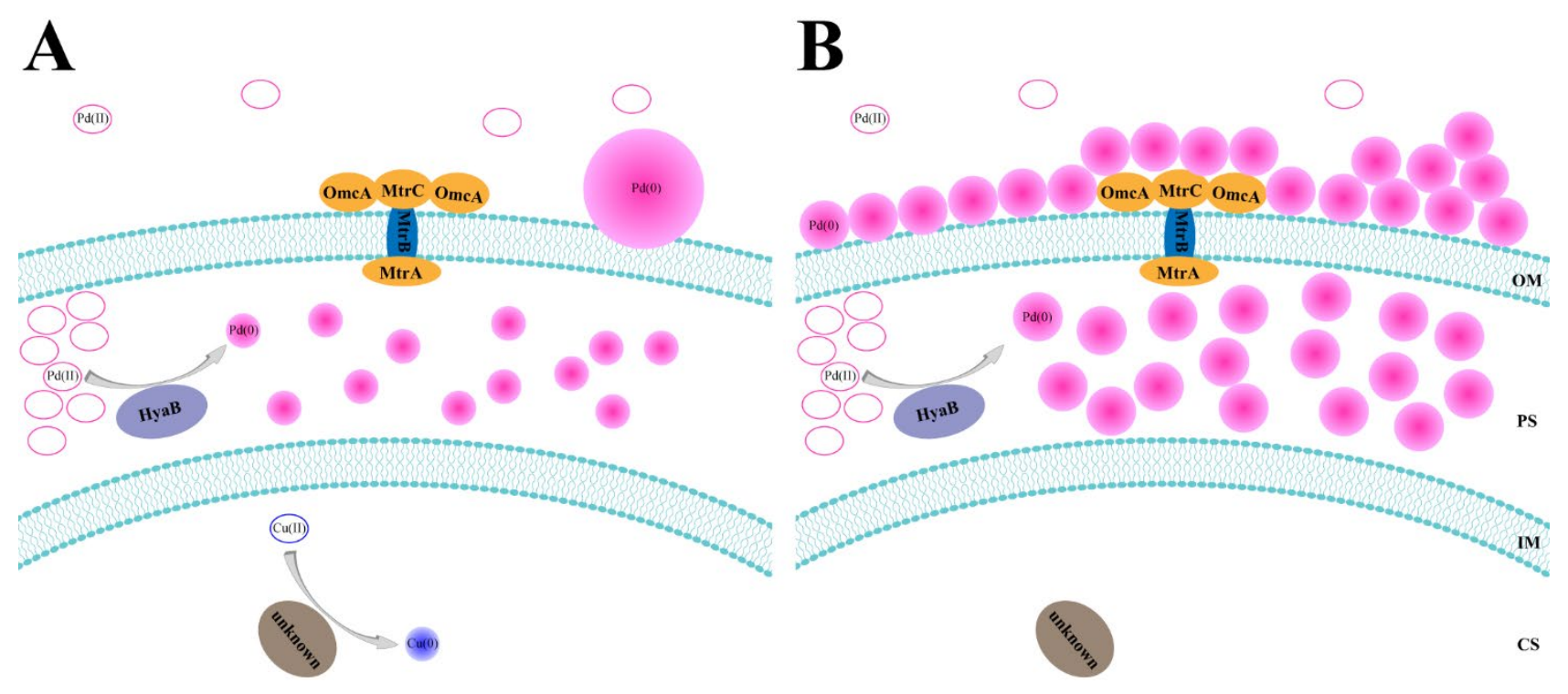

Figure 6. Proposed effect of $\mathrm{Cu}(\mathrm{II})$ on the formation of PdNPs. The morphologies and distribution of PdNPs produced by MR-1 incubated in media containing Pd(II) (A) with and (B) without $\mathrm{Cu}(\mathrm{II})$. OM: outer membrane; PS: periplasm; IM: inner membrane. 
To sum up, $\mathrm{Cu}$ (II) does not interfere with the sorption of $\mathrm{Pd}(\mathrm{II})$ from the medium, but with both the transportation of $\operatorname{Pd}(0)$ across the outer membrane and with PdNP growth. As a result, different morphologies of PdNPs form when $\mathrm{Cu}(\mathrm{II})$ is present in the medium.

\section{Conclusions and Perspectives}

The effect of $\mathrm{Cu}(\mathrm{II})$ on $\mathrm{Pd}(\mathrm{II})$ removal by MR-1 differs from other microorganisms, e.g., E. coli. A decrease of $\mathrm{Pd}(\mathrm{II})$ removal by $\mathrm{Cu}(\mathrm{II})$ is observed but only to a mild degree. MR-1 cells remove as much as $89.8 \%$ of $\mathrm{Pd}(\mathrm{II})$ in $24 \mathrm{~h}$ in the presence of $\mathrm{Cu}(\mathrm{II})$, which is close to the removal efficiency of $98.7 \%$ in the absence of $\mathrm{Cu}(\mathrm{II})$. The slower $\mathrm{Cu}(\mathrm{II})$ removal after $\mathrm{Pd}(\mathrm{II})$ addition suggests competition between $\mathrm{Cu}(\mathrm{II})$ reduction and $\mathrm{Pd}(\mathrm{II})$ reduction. Apparent morphological differences between the NPs harvested from the media with and without $\mathrm{Cu}(\mathrm{II})$ are observed. Small PdNPs inside the cells, smooth cellular surfaces with a few large PdNPs, and incomplete Pd(II) reduction are observed in the presence of $\mathrm{Cu}(\mathrm{II})$ in the media. Dense and homogeneous layers of PdNPs fully cover the cells incubated in media free of $\mathrm{Cu}(\mathrm{II}) . \mathrm{Cu}(\mathrm{II})$ inhibition of $\mathrm{Pd}$ crystal growth and $\mathrm{Pd}(0)$ transfer from the periplasm to extracellular space are therefore proposed.

Phosphate buffer is not crucial to Pd(II) biosynthesis. Phosphate slightly increases the harvest of Pd(II), but also precipitates other metals, for example, $\mathrm{Cu}(\mathrm{II})$. Metal precipitation normally complicates the biosynthesis. Media more compatible with copper solubilization, such as $0.9 \% \mathrm{NaCl}$ solution, are perhaps better alternatives. Overall our study suggests that $\mathrm{Cu}(\mathrm{II})$ may not have any major effect on $\mathrm{Pd}(\mathrm{II})$ removal from aqueous system by MR-1, but strongly affects the morphologies of recovered PdNPs. Moreover, the addition of phosphate buffer into the media is not critical to the PdNP biosynthesis.

Morphological regulation of nanomaterials is highly valuable since many properties of nanomaterials (catalytical activity, specific surface area, bandgap, etc.) are determined by their morphologies. The current study offers a practical method to PdNP morphology control by introducing a co-existing metal or phosphate buffer into the medium. Future research could be extended to the effect of $\mathrm{Cu}(\mathrm{II})$ on the biosynthesis of other metals, e.g., Au, Pt, Fe, and Se. The microbial active sites of these metals are not identical and different effects therefore expected. In addition, since microbes are live complexes of 
different elements, chemical elements microbially made up or secreted in the microbial metabolism potentially participate in the microbial biosynthesis of nanomaterials. The biosynthesis processes are therefore different from processes in chemical synthesis with well-known components. The different effective composition in biosynthesis and chemosynthesis and the resultant dissimilar morphologies may be responsible for the different performance of biogenic and chemogenic nanomaterials, as for example, in the unique electrocatalytic selectivity of the biogenic PdNPs. ${ }^{[5]}$

\section{Acknowledgements}

This work is devoted to the memory of Prof. Jingdong Zhang. All the authors are grateful to Professor Zhang for her never-failing inspiration, hard work, guidance and enthusiasm in her scientific research, as a supervisor and long-time fine colleague. She will be deeply missed.

\section{Conflict of Interest}

The authors declare no conflict of interest.

[1] Z. Zheng, Y. Xiao, F. Zhao, J. Ulstrup, J. Zhang in Bacterially generated nanocatalysts and their applications, Vol. 1342, American Chemical Society, 2020, pp.97-122.

[2] J. Varia, A. Zegeye, S. Roy, S. Yahaya, S. Bull Biochem. Eng. J. 2014, 85, 101-109.

[3] S. K. Srivastava, M. Constanti J. Nanopart. Res. 2012, 14, 831.

[4] J. Liu, Y. Zheng, Z. Hong, K. Cai, F. Zhao, H. Han Sci. Adv. 2016, 2, e1600858.

[5] R. Wu, X. Tian, Y. Xiao, J. Ulstrup, H. E. Molager Christensen, F. Zhao, J. Zhang J. Mater. Chem. A. 2018, 6, 1065510662.

[6] W. Sun, X. Sun, B. Li, R. Xu, L. Y. Young, Y. Dong, M. Zhang, T. Kong, E. Xiao, Q. Wang Environ. Int. 2020, 138, 105601 .

[7] Z. Zheng, Y. Zheng, X. Tian, Z. Yang, Y. Jiang, F. Zhao Environ. Pollut. 2018, 241, $265-271$.

[8] Y. Zheng, C. Wang, Z. Zheng, J. Che, Y. Xiao, Z. Yang, F. Zhao RSC Adv. 2014, 4, 62544-62549.

[9] Z. Wang, Z. Zheng, S. Zheng, S. Chen, F. Zhao J. Power Sources. 2015, 287, 269-275.

[10] R. Xu, B. Li, E. Xiao, L. Y. Young, X. Sun, T. Kong, Y. Dong, Q. Wang, Z. Yang, L. Chen, W. Sun Environ. Pollut. 2020, 261, 114226 .

[11] K. Deplanche, I. Caldelari, I. P. Mikheenko, F. Sargent, L. E. Macaskie Microbiology. 2010, 156, 2630-2640. 
[12] K. Deplanche, L. E. Macaskie Biotechnol. Bioeng. 2008, 99, 1055-1064.

[13] A. Okamoto, R. Nakamura, K. H. Nealson, K. Hashimoto ChemElectroChem. 2014, 1, 1808-1812.

[14] Y. Xiao, E. Zhang, J. Zhang, Y. Dai, Z. Yang, H. E. M. Christensen, J. Ulstrup, F. Zhao Sci. Adv. 2017, 3 , e1700623.

[15] Z. Zheng, Y. Xiao, R. Wu, H. E. Mølager Christensen, F. Zhao, J. Zhang Biosens. Bioelectron. 2019, $142,111571$.

[16] Y. Hu, J. Zhang, J. Ulstrup Langmuir. 2010, 26, 9094-9103.

[17] C. Engelbrekt, K. H. Sorensen, J. Zhang, A. C. Welinder, P. S. Jensen, J. Ulstrup J. Mater. Chem. 2009, 19, $7839-7847$.

[18] C. Engelbrekt, K. H. Sørensen, T. Lübcke, J. Zhang, Q. Li, C. Pan, N. J. Bjerrum, J. Ulstrup ChemPhysChem. 2010, $11,2844-2853$.

[19] J. K. Grady, N. D. Chasteen, D. C. Harris Anal. Biochem. 1988, 173, 111-115.

[20] C. M. H. Ferreira, I. S. S. Pinto, E. V. Soares, H. M. V. M. Soares RSC Adv. 2015, 5, 30989-31003.

[21] D.-H. Kim, M.-G. Kim, S. Jiang, J.-H. Lee, H.-G. Hur Environ. Sci. Technol. 2013, 47, 8709-8715.

[22] X. Wu, F. Zhao, N. Rahunen, J. R. Varcoe, C. Avignone-Rossa, A. E. Thumser, R. C. T. Slade Angew. Chem. Int. Ed. 2010, 50, 427-430.

[23] R. Wu, L. Cui, L. Chen, C. Wang, C. Cao, G. Sheng, H. Yu, F. Zhao Sci. Rep. 2013, 3, 3307.

[24] J. Zhang, A. M. Kuznetsov, J. Ulstrup J. Electroanal. Chem. 2003, 541, 133-146.

[25] Q. Chi, J. Zhang, J. U. Nielsen, E. P. Friis, I. Chorkendorff, G. W. Canters, J. E. T. Andersen, J. Ulstrup J. Am. Chem. Soc. 2000, 122, 4047-4055.

[26] X. Hao, J. Zhang, H. E. M. Christensen, H. Wang, J. Ulstrup ChemPhysChem. 2012, 13, 2919-2924.

[27] J. R. Lloyd, P. Yong, L. E. Macaskie Appl. Environ. Microbiol. 1998, 64, 4607.

[28] R. Ganesh, K. G. Robinson, L. Chu, D. Kucsmas, G. D. Reed Water Res. 1999, 33, 3447-3458.

[29] C. K. Ng, T. K. Cai Tan, H. Song, B. Cao RSC Adv. 2013, 3, 22498-22503.

[30] R. L. Kimber, E. A. Lewis, F. Parmeggiani, K. Smith, H. Bagshaw, T. Starborg, N. Joshi, A. I. Figueroa, G. van der Laan, G. Cibin, D. Gianolio, S. J. Haigh, R. A. D. Pattrick, N. J. Turner, J. R. Lloyd Small. 2018, 14, 1703145.

[31] H. Xu, L. Tan, H. Cui, M. Xu, Y. Xiao, H. Wu, H. Dong, X. Liu, G. Qiu, J. Xie J. Mol. Liq. 2018, 255, 333-340.

[32] Y.-s. E. Lin, R. D. Vidic, J. E. Stout, C. A. McCartney, V. L. Yu Water Res. 1998, 32, 1997-2000.

[33] M. Valodkar, S. Modi, A. Pal, S. Thakore Mater. Res. Bull. 2011, 46, 384-389.

[34] L. Cui, P. Chen, S. Chen, Z. Yuan, C. Yu, B. Ren, K. Zhang Anal. Chem. 2013, 85, 5436-5443.

[35] Z. Vardanyan, A. Trchounian Cell Biochem. Biophys. 2010, 57, 19-26.

[36] T. A. Voeikova, A. S. Shebanova, Y. D. Ivanov, A. L. Kaysheva, L. M. Novikova, O. A. Zhuravliova, V. V. Shumyantseva, K. V. Shaitan, M. P. Kirpichnikov, V. G. Debabov Appl. Biochem. Microbiol. 2016, 52, 769-775.

[37] L. Xiong, J. Chen, Y. Huang, W. Li, J. Xie, H. Yu Nano Energy. 2015, 12, 33-42. 
[38] H. Sun, L. Cao, L. Lu Energy Environ. Sci. 2012, 5, 6206-6213.

[39] H. Cao, X. Wang, H. Gu, J. Liu, L. Luan, W. Liu, Y. Wang, Z. Guo RSC Adv. 2015, 5, 34566-34571.

[40] C. O. Kappe, D. Dallinger Nat. Rev. Drug Discovery. 2006, 5, 51-63.

[41] R. F. Egerton, Physical principles of electron microscopy: An introduction to TEM, SEM, and AEM, Springer US, 2005.

[42] H. Cao, X. Xiao, X. Wang, J. Liu, P. Si Electrochim. Acta. 2020, 330, 135260.

[43] H. Cao, Z. Zheng, J. Meng, X. Xiao, P. Norby, S. Mossin Electrochim. Acta. 2020, 356, 136791.

[44] H. Wang, Z. Sun, Y. Yang, D. Su Nanoscale. 2013, 5, 139-142.

[45] P. Li, W. Lv, S. Ai J. Exp. Nanosci. 2016, 11, 18-27.

[46] G. Zheng, E. I. Altman Surf. Sci. 2000, 462, 151-168.

[47] K. Chourey, M. R. Thompson, J. Morrell-Falvey, N. C. VerBerkmoes, S. D. Brown, M. Shah, J. Zhou, M. Doktycz, R. L. Hettich, D. K. Thompson Appl. Environ. Microbiol. 2006, 72, 6331.

[48] S. A. Patil, K. Górecki, C. Hägerhäll, L. Gorton Energy Environ. Sci. 2013, 6, 2626-2630. 


\section{Table of Contents}

$\mathrm{Cu}(\mathrm{II})$ in the medium significantly affects the morphologies of Pd nanoparticles (PdNPs) synthesized by Shewanella oneidensis MR-1 by inhibiting $\operatorname{Pd}(0)$ transfer across the outer membrane and PdNP crystal growth in the periplasm, but not the sorption of Pd(II). Therefore, 5-nm PdNPs densely envelop the Shewanella oneidensis MR-1 and accumulate significantly in the periplasm in the absence of $\mathrm{Cu}(\mathrm{II})$, while 4-nm PdNPs are evenly distributed in the periplasm, and the cellular surface is smooth in the presence of $\mathrm{Cu}(\mathrm{II})$.

Keywords: biosynthesis; copper ion; extracellular electron transfer; palladium nanoparticles; Shewanella oneidensis

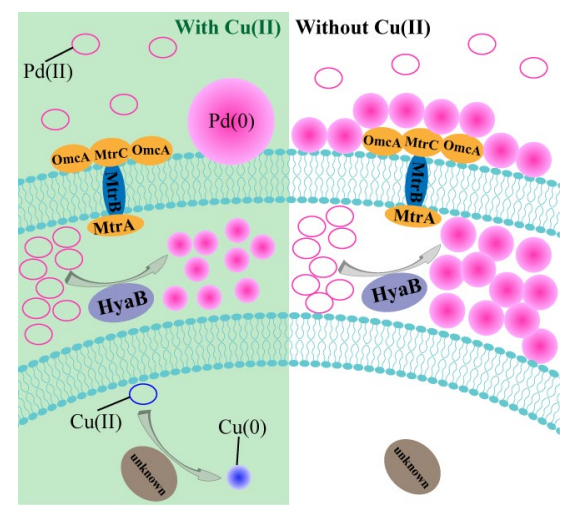

